\title{
Do corporate Web sites in Africa communicate investor information according to best practice guidelines?
}

\author{
G. Nel \\ Department of Accounting \\ University of Stellenbosch \\ Stellenbosch \\ South Africa \\ gfn@sun.ac.za

\section{R. Baard} \\ Department of Accounting \\ University of Stellenbosch \\ Stellenbosch \\ South Africa \\ rbaard@sun.ac.za
}

Corporate Web sites have become very popular media of information over the past decade. The Investor Relations Society published best practice Web site guidelines in December 2006 to guide companies seeking to improve the quality of their on-line communication with investors via their corporate Web sites. Guidelines were given for presentation (the way in which information is communicated) and content (the information that is communicated). This study focused only on content. A 20-point checklist was developed from the prescribed best practice. The checklist focused on the six categories of best practice that entail company information, annual reports of the current year and archive, relevant news, shareholder information, bondholder information, corporate governance and corporate responsibility. Seventy-eight companies in Africa (40 from South Africa and 38 from the 'rest of Africa', that is Egypt, Kenya, Morocco, Nigeria and Tunisia) were evaluated against this checklist. Companies from the 'rest of Africa' rated lower than South African companies in all categories on the checklist. Although South African companies received ratings above $90 \%$ for all categories, besides bondholder information, many of these companies do not supply shareholder, corporate governance and corporate responsibility information via dedicated sections on their corporate Web sites. The results for companies from the 'rest of Africa' were disappointing, especially with regard to communication of annual reports, shareholder information, bondholder information and corporate responsibility. Although possible reasons for these disappointing results are discussed in this study, further research should be conducted to determine the reason(s) why important elements of information are not communicated via corporate Web sites.

Key words: Content of investor relations; investor relations; corporate Web sites; Africa; investor relations 


\section{Contents}

1. Introduction and background

2. Objective of study and methodology

3. Selection of companies

4. Best practice for content

4.1 Company information

4.2 Financial data

4.3 Relevant news

4.4 Shareholder information

4.5 Bondholder information

4.6 Corporate governance

4.7 Corporate responsibility

5. Empirical research and results

5.1 Development of a checklist to evaluate companies

5.2 Evaluation of company Web sites

5.3 Results

6. Conclusion

7. References

8. Appendix A

9. Appendix B

\section{Introduction and background}

Investors have a vast number of opportunities to invest in different countries and in different types of assets. One of these potential opportunities is investment in listed companies on the stock exchange of a specific country. To evaluate such a potential investment, investors require detailed financial and nonfinancial information about the listed companies. This information is available in various forms. The investor could request (a) hard copies of the required information from the company or they could request the information by (b) e-mail. Information can also be obtained in the (c) published media or under the (d) investor relations section of the corporate Web site of a company.

The significance for investors of corporate Web sites as a source of information is accentuated in a study conducted by Makinson Cowell (2000), which concluded that $75 \%$ of institutional investors usually or occasionally review corporate Web sites before meeting a company's management.

According to Robert Seberger, president of Investor Relations Marketing, the 'Big Four' components of corporate Web sites are investor relations, public relations, employment and 'about us' (Investor Relations Marketing 2006). Marston (1996) defines investor relations (IR) as the link between a company and the financial community by which information for evaluating the company is provided to the financial community (investors). Given this definition of IR, it is clear that investors will be particularly interested in the IR section when visiting a corporate Web site.

The Investor Relations Society (2006) published best practice Web site guidelines in December 2006 to guide companies seeking to improve the quality of their on-line communication with investors via their corporate Web sites. The guidelines aim to highlight best practice from the perspective of shareholder communication. These guidelines focus on the way in which content is delivered (presentation style), as well as the actual information (content) that is delivered. The presentation of IR only considers the way in which the content is delivered, not the specific content itself. The content section of best practice concentrates on the actual content that companies should consider for inclusion on their corporate Web site. These best practices are based on observations of the many examples of good practice that can be found on listed company Web sites.

Research by Baard and Nel (2006) has evaluated the compliance of corporate Web sites of companies in Africa with best practice Web site guidelines relating to presentation. This article will therefore not consider best practice relating to presentation but will look at content only.

The IR information on a corporate Web site will be of little value to the investor if the correct content, if any, is not being supplied by this medium. The corporate Web site of the company should be the one 
access point to all the various types of financial and non-financial information regarding the company. The investor receives no benefit from a corporate Web site that presents content that is unusable, irrelevant and incomplete. In such instances the investor will rather make use of the traditional sources of information. The knowledge of the investor and his or her understanding of the company should be improved when the content of the corporate Web site is accessed.

The purpose of this study was to investigate and evaluate the content of the IR information communicated via the corporate Web sites of African companies against the best practice guidelines for the content thereof as published by the Investor Relations Society (2006).

\section{Objective of study and methodology}

The primary objective of this study was to investigate and evaluate the content of investor information that is communicated by companies in Africa to investors via corporate Web sites against the best practice guidelines for content of investor communications as published by the Investor Relations Society (2006). The secondary objective was to compare South African companies with companies in the 'rest of Africa', excluding South Africa.

To accomplish these objectives the following methodology was followed in this study:

1. Based on research by Baard and Nel (2006), companies were selected for inclusion in this study.

2. Best practice guidelines for content as published by the Investor Relations Society were discussed and summarized to obtain a checklist that could be used to evaluate and compare compliance with best practice guidelines in an unbiased and simplified manner.

3. Companies that were selected were evaluated against the checklist of best practice guidelines.

\section{Selection of companies}

As the objective of this study was to investigate and evaluate the content of investor relation information communicated via corporate Web sites, only companies with corporate Web sites and dedicated IR sections were included in this study. Research by Baard and Nel (2006) found that only 173 of 240 (72\%) selected companies in Africa have working corporate Web sites.

Of these 173 companies, only 78 included a dedicated IR section on their corporate Web sites. These 78 companies were investigated in this study. For a list of these companies and their Web site addresses, see Appendix A.

The research undertaken by Baard and Nel (2006) showed a clear divergence between South African companies and companies in the 'rest of Africa'. All the South African companies (40) that were investigated had working corporate Web sites and dedicated IR sections. Only 133 of the 200 (40 each from Egypt, Kenya, Morocco, Nigeria and Tunisia) in the 'rest of Africa' had working Web sites and only 38 of the 133 had a dedicated IR section. In the comparison between South African companies and companies from the 'rest of Africa', the 40 companies from South Africa and 38 from the 'rest of Africa' were used. Appendix A gives information on each company's country of origin.

\section{Best practice for content}

Best practice guidelines published by the Investor Relations Society (2006) for investor communication entail both presentation (how the information should be communicated) and content (what information should be communicated). As already discussed, this study investigated content only.

According to identified best practice, the following types of information should be communicated to investors via corporate Web sites: company information, financial data, relevant news, shareholder information, bondholder information, corporate governance and corporate responsibility. These seven 
types of information will now be briefly discussed.

\subsection{Company information}

This entails information about the company from an investment perspective. Suggested ways to provide this information include an 'about us' section, detailed fact books or short one- to two-page fact sheets and management profiles (e.g. interviews, speeches and videos to explain the company, its strategy and management's vision).

\subsection{Financial data}

Investors need financial data to quantify expected returns and risks of an investment in a company. Although financial data primarily consist of the annual report (all the financial statements, director's and auditor's report), best practices include 14 key points to consider in the inclusion of financial data. These key points include an archive of annual reports; key financial ratios; relevant information on main intangibles (including those not shown on the balance sheet); dividend history; share price history; financial presentations; and key performance indicators (both financial and non-financial).

\subsection{Relevant news}

The purpose of relevant news is to keep investors up to date with news about the company, its strategy and operating environment. It is regarded as important to have a central point of access to all news releases about the company.

\subsection{Shareholder information}

Best practice proposes a dedicated shareholder information section. This section should provide information on shareholder meetings; important dates for shareholders; contact details of company advisors; and share price movements and announcements. It should also facilitate shareholder administration, either by on-line management of shareholder information or by providing the information and relevant documentation for investors to download.

To enable current and potential investors to obtain information about the company or its shares, contact details for the IR officer or team responsible for shareholder communication should also be provided.

\subsection{Bondholder information}

Companies should provide clear information on their corporate debt situation and should include information such as credit ratings, terms of banking covenants and contact details for investors with queries relating to the debt situation.

\subsection{Corporate governance}

Companies are managed on behalf of shareholders by directors. Corporate governance gives information on how a company is managed. According to the Investor Relations Society's best practice guidelines, a corporate Web site should reflect the importance of corporate governance for investors by identifying this in the main investor index. Web sites should therefore provide a dedication section on corporate governance.

This section should include information about the company (such as its strategy, vision, products and services that it supplies and current changes), its directors (biographical details, appointment, remuneration, their interest in the company and share transactions) and the audit committee.

\subsection{Corporate responsibility}

The corporate Web site should contain information about the company's corporate responsibility policies and data. Corporate responsibility includes all environmental, social, health and safety issues and the management of risks across the company.

Possible information that could be supplied includes details of the individual(s) who are responsible for 
such policies, internal arrangements for implementation of these policies, a statement of specific policies (such as energy consumption, recycling of waste, carbon dioxide emissions, etc.) and policy objectives (e.g. maximum carbon dioxide emissions per annum).

\section{Empirical research and results}

\subsection{Development of a checklist to evaluate companies}

To guide companies in their on-line communication with investors, the Investor Relations Society (2006) gives 65 hints or key points to consider for inclusion on corporate Web sites.

Given the magnitude of the present study (78 companies were investigated) and to simplify the results and discussion thereof, this study only considered the inclusion or not of the following elements on corporate Web sites:

- Company information (could be supplied with an 'about us' section, fact book, fact sheets or management profiles)

- Financial data

○ Annual report

- Archive of annual reports

- A central point of access to all relevant news releases

- A dedicated shareholder information section

- Bondholder information (any information on the company's corporate debt situation)

- A dedicated corporate governance section

- A dedicated corporate responsibility section.

See Appendix B for the checklist used in this study.

\subsection{Evaluation of company Web sites}

All Web sites were evaluated in a two-week period during June 2007. Time spent to evaluate Web sites was limited to 15 minutes per Web site. The rationale behind this was that important information should be available easily and at first glance to users of corporate Web sites. If specific information could not be found, the search facility, if available, was used.

Although all the Web sites investigated in this study have IR sections and all the information included in the checklist was of an IR nature, it is not a best practice to group all IR communication under the IR section. To complete the checklist, both the dedicated IR section and the remainder of the corporate Web site were therefore investigated.

Although best practice guidelines for content suggest dedicated sections for relevant news, shareholder information, corporate governance and corporate responsibility, corporate Web sites without dedicated sections were screened for the availability of bits and pieces of this information, either under the IR section or in the remainder of the Web site.

During the evaluation, it was accepted that different companies and especially different countries would use different terminology for the different elements investigated. The following are a few examples of different names used for the different elements of the checklist:

Company information: About us

Relevant news: Media centre, news, news and media, press room

Shareholder information: Equity shareholders, shares, share information

Bondholder information: Credit rating, debt investors

Corporate responsibility: Sustainability, sustainability reports, sustainable development, global reporting initiative, corporate social investment, social, policies, corporate citizenship.

It should also be noted that the quality and completeness of information supplied was not evaluated in this study. As discussed above, shareholder information should, for example, include information about 
shareholder meetings, important dates for shareholders, contact details of company advisors and share price movements and announcements. It should also facilitate shareholder administration, either by online management of shareholder information or by providing the information and relevant documentation for investors to download. If a company supplied only one element of shareholder information, for example share price movements, it was taken that shareholder information was supplied and the checklist was marked.

In the discussion of the results, examples will be given of companies that supplied all or the majority of best practice key points under each of the checklist elements compared to companies that supplied only one or two of the required best practice key points.

\subsection{Results}

The 78 corporate Web sites were evaluated according to the checklist (Appendix B). In Table 1, below, the results are summarized for the 40 South African companies, 38 companies from the 'rest of Africa' and the 78 companies for Africa as a whole.

The corporate Web sites of three companies in Morocco could not be accessed as one Web site was not working and two Web sites were only available in French, with no link to translate the Web site into English. As these three corporate Web sites were not accessible, they were evaluated as not complying with best practice guidelines.

Table 1 Summarized checklist results

\begin{tabular}{|c|c|c|c|}
\hline & South Africa (40) & Rest of Africa (38) & Total Africa (78) \\
\hline Company Information & $40(100 \%)$ & $35(92 \%)$ & $75(96 \%)$ \\
\hline Investor relations & 39 & 34 & 73 \\
\hline Web site & 1 & 1 & 2 \\
\hline Financial - Annual Reports & $40(100 \%)$ & $30(79 \%)$ & $70(90 \%)$ \\
\hline Investor relations & 40 & 29 & 69 \\
\hline Web site & 0 & 1 & 1 \\
\hline \multicolumn{4}{|l|}{ Financial - Reports Archive } \\
\hline Annual reports - archive & $40(100 \%)$ & $29(76 \%)$ & $69(88 \%)$ \\
\hline Archive - years & 5,6 & 4,4 & 5,1 \\
\hline Relevant News & $39(98 \%)$ & $34(89 \%)$ & $73(94 \%)$ \\
\hline Investor relations & 0 & 0 & 0 \\
\hline Dedicated section & 38 & 32 & 70 \\
\hline Web site & 1 & 2 & 3 \\
\hline Shareholder Information & $37(93 \%)$ & $27(71 \%)$ & $64(82 \%)$ \\
\hline Investor relations & 20 & 17 & 37 \\
\hline Dedicated section & 15 & 9 & 24 \\
\hline Web site & 2 & 1 & 3 \\
\hline Bondholder Information & $15(38 \%)$ & $9(24 \%)$ & $24(31 \%)$ \\
\hline Investor relations & 12 & 9 & 21 \\
\hline Web site & 3 & 0 & 3 \\
\hline
\end{tabular}




\begin{tabular}{|l|l|l|l|} 
Corporate Governance & $\mathbf{4 0} \mathbf{( 1 0 0 \% )}$ & $\mathbf{3 2} \mathbf{( 8 4 \% )}$ & $\mathbf{7 2} \mathbf{( 9 2 \% )}$ \\
\hline Investor relations & 4 & 3 & 7 \\
\hline Dedicated section & 30 & 12 & 42 \\
\hline Web site & 6 & 17 & 23 \\
\hline & & & \\
\hline Corporate Responsibility & $\mathbf{3 8} \mathbf{( 9 5 \% )}$ & $\mathbf{2 1} \mathbf{( 5 5 \% )}$ & $\mathbf{5 9} \mathbf{( 7 6 \% )}$ \\
\hline Investor relations & 3 & 1 & 4 \\
\hline Dedicated section & 32 & 17 & 49 \\
\hline Web site & 3 & 3 & 6 \\
\hline
\end{tabular}

\subsubsection{Company information}

Most of the companies (96\%) in this study communicated information about themselves on their corporate Web site. This was mainly done by means of an 'About Us' section on the corporate Web site, where various kinds of information about the company were communicated.

\subsubsection{Financial data: annual reports and archive}

All of the South African companies supplied their annual reports and an archive of annual reports of an average of 5,6 years on their corporate Web site. All of these annual reports were available under the IR section of these corporate Web sites. Table 1 illustrates that only $79 \%$ (30 companies) of the 'rest of Africa' companies had annual reports available on their corporate Web sites and only 76\% (29 companies) had an archive of annual reports of an average of 4,4 years. This means that eight of these companies did not supply annual reports on their corporate Web sites, or that these were either not accessible or not available in English. This is not satisfactory as one would expect that a listed company would at least have its annual report and archive of annual reports available to investors on the corporate Web site.

\subsubsection{Relevant news}

According to Table 1, all of the South African companies except one communicated relevant company news on their corporate Web sites. Four companies from the 'rest of Africa' did not communicate any relevant company news on their corporate Web sites, or the site was either not accessible, or was not available in English. In this study, 70 companies (out of 73 that did supply relevant news) communicated relevant company news via a dedicated section on the corporate Web site. A good example of the corporate Web site of a company that communicated relevant news according to best practice guidelines is Anglogold Ashanti Limited (www.anglogold.com). This company provided easy access to all press releases for the current year and archived press releases back to 2004, a photo library of people, marketing and operations in the press and relevant contact details at Anglogold. Compared to this, no news items could be found for Steinhoff International Holdings (www.steinhoffinternational.com).

\subsubsection{Shareholder information}

Table 1 illustrates that 93\% (37 companies) of South African companies communicated shareholder information on their corporate Web sites. Of these companies, 15 had a dedicated section for shareholder information, giving the investor easy access to a central point of shareholder information. The remaining South African companies communicated shareholder information by supplying bits and pieces of information in various sections of their corporate Web sites. Only 71\% (27 companies) of the 'rest of Africa' companies communicated any shareholder information and only nine had a dedicated section for shareholder information, making it harder for the investor to find the required information. Eleven companies from the 'rest of Africa' did not communicate any shareholder information to investors, or this was either not accessible or not available in English. Remgro Limited (www.remgro.co.za) is an example of a company that reflected almost all of the best practice key points compared to Discovery Holdings Limited (www.discovery.co.za) that provided only the current share price for the company.

\subsubsection{Bondholder information}

Very few companies (38\% in South Africa and 24\% in the rest of Africa) communicated any bondholder information via their corporate Web sites. Although some bondholder information, for example debt ratios, can be calculated from annual reports, other types of bondholder information, for example credit ratings, must specifically be supplied. The study found that, when companies did communicate bondholder information, it was mainly available under the IR section of the corporate Web site. 


\subsubsection{Corporate governance}

According to Table 1, all of the South African companies communicated information on corporate governance via their corporate Web sites. Thirty (75\%) of these companies had a dedicated section for corporate governance on their corporate Web site, grouping together all the relevant corporate governance information at one access point. Harmony Limited (www.harmony.co.za) had a dedicated section for corporate governance and reflected almost all best practice key points compared to the MTN group (www.mtn.co.za) that provided only bits and pieces of corporate governance information, such as a list of directors and management, under the heading Explore the MTN Group.

Thirty-two (84\%) of the 'rest of Africa' companies did communicate corporate governance information via their corporate Web sites, but only 12 companies did so by means of a dedicated section. The rest of the 20 companies communicated corporate governance information that was mostly scattered through the remainder of the corporate Web site, making it hard for the investor to find the required corporate governance information.

\subsubsection{Corporate responsibility}

Table 1 illustrates that 38 (95\%) of the South African companies communicated information on corporate responsibility, and most (32 companies) did so by means of a dedicated section. BHP Billiton (www.bhpbilliton.com) had a dedicated section for corporate responsibility (referred to as sustainable development) and provided almost all best practice key points compared to Liberty International (www.liberty-international.com) for which no information on any corporate responsibility issues could be found.

Only 21 companies (55\%) of the 'rest of Africa' companies communicated any information on corporate responsibility via their corporate Web sites. This is not satisfactory as one would expect that a listed company would communicate corporate responsibility information to its various investors and other stakeholders. The 'rest of Africa' companies that did communicate this type of information, mostly had a dedicated section for it on their corporate Web sites.

\section{Conclusion}

The majority of the selected companies depend on investors for capital to maintain and expand business operations. Investors require specific information to evaluate investments. Companies and investors have various alternatives to respectively distribute and gather this information. Corporate Web sites have become very popular media of information over the past decade.

The Investor Relations Society (2006) published best practice Web site guidelines in December 2006 to guide companies seeking to improve the quality of their on-line communication with investors, via their corporate Web sites. These guidelines focused separately on presentation (the way in which information is delivered) and on the content of the information itself.

This study only investigated best practice for content and for this a 20-point checklist, focusing on the six main best practice guidelines for content, was developed to investigate 78 companies in Africa (40 from South Africa and 38 from the 'rest of Africa').

All elements of the checklist showed that there was a clear divergence from compliance with best practice guidelines between South African companies and companies in the 'rest of Africa'. All companies in South Africa provide company information, latest annual reports, archive annual reports and corporate governance information, compared to respectively $92 \%, 79 \%, 76 \%$ and $84 \%$ of companies in the 'rest of Africa'.

Given the importance of annual reports to investors, it is unacceptable for companies, and especially companies of the size investigated in this study, not to supply annual reports on their Web sites.

Concerning the section on relevant news, $98 \%$ of the companies in South Africa and $89 \%$ of these in the 'rest of Africa' communicate relevant company news via their corporate Web sites.

Although the majority of companies in South Africa do supply shareholder, corporate governance and corporate responsibility information (respectively 93\%, 100\% and 95\%), not all companies in South 
Africa supply such information via dedicated sections. It is not only much more user friendly if all relevant information is gathered under one heading, but it also decreases the risk of investors missing important pieces of information. Only 40,5\%, 75\% and 84\% of companies in South Africa use dedicated sections to distribute shareholder, corporate governance and corporate responsibility information respectively.

Although this is not very desirable, it is far better than companies in the 'rest of Africa' where only $71 \%$, $84 \%$ and $55 \%$ respectively provide shareholder, corporate governance and corporate responsibility information. Of these companies only 33\%, 37,5\% and $81 \%$ have dedicated sections respectively for shareholder, corporate governance and corporate responsibility information.

The worst compliance with the prescribed best practice guidelines occurs with bondholder information. Here only 38\% of companies in South Africa and only $24 \%$ in the 'rest of Africa' provide such information.

Given the magnitude of the companies that were evaluated and the relatively low cost (Baard and Nel 2006) of developing and managing a corporate Web site, one would expect that all listed companies that have a working corporate Web site with a dedicated IR section, would communicate at least the six main categories as prescribed by the best practice guidelines of the Investor Relations Society (2006). The results for the companies in the 'rest of Africa' are unacceptable. These companies number among the top 40 companies in five of the larger economies in Africa. These companies do not optimally utilize their corporate Web sites to communicate to investors.

Although the top 40 South African companies communicate most of the six main categories as prescribed by best practice guidelines, some of the information is not available in dedicated sections of the corporate Web sites. As indicated above, finding information in dedicated sections on the corporate Web sites of companies is more user-friendly for the investor. The authors of this study also found that corporate Web sites that do have dedicated sections for the different types of information communicated, tend, in general, to supply more information that complies with the key points of the best practice guidelines. Finding the required information on these corporate Web sites tends to be easier and faster as all relevant information is grouped together.

Possible reasons for the disappointing results for the 'rest of Africa' companies could involve the lack of the necessary skills or available technology to develop and manage corporate Web sites. The 'rest of Africa' companies may also perceive that African investors, especially, do not use the Internet to find company information before making decisions. These reasons may, however, no longer be a factor. All African countries have Internet access, with the majority having international bandwidth use of more than $64 \mathrm{Kbps}$, which is a big improvement from five years ago when only four countries in Africa had an international bandwidth of more than 64Kbps (African Internet Connectivity, 2006).

Cost cannot be a limiting factor (Baard and Nel, 2006). The costs associated with developing and hosting a corporate Web site is low compared to the perceived benefits of having a corporate Web site that communicates all the relevant information. A corporate Web site allows a company to communicate company information in a manner that is far cheaper, more flexible and more immediate than conventional communication media, such as hard copies of information or the printed media.

A possible reason for the lack of corporate governance and corporate responsibility on the corporate Web sites of the 'rest of Africa' companies could be that these companies do not have policies for these items and therefore do not see the need to communicate such information on their corporate Web sites.

The only remaining reasons that the authors of this study are able to offer for these poor results for the 'rest of Africa' companies in terms of the lack of annual reports, relevant company news and shareholder information, are that these companies are either negligent, do not perceive it important to communicate information to investors via corporate Web sites, or do not realize the benefits of communicating company information in this manner.

Further research should be conducted to determine the reason(s) for the lack of compliance by the 'rest of Africa' companies with best practices of communicating information via corporate Web sites. 


\section{References}

African Internet Connectivity. Maps and tables. 2006. Available WWW:

http://www3.sn.apc.org/africa/afrmain.htm (Accessed 2 March 2006).

Baard, R.S. and Nel, G.F. 2006. Using corporate Web sites to market to investors in Africa. South African Journal of Information Management, 8(3). Available WWW: http://www.sajim.co.za (Accessed 18 May 2007).

Investor Relations Marketing. 2006. Investor Relations Website Design. Available WWW: http://www.investorrelationsmarketing.com (Accessed 2 March 2006).

Investor Relations Society. 2006. Available WWW: http://www.ir-soc.org.uk (Accessed 18 May 2007).

Investor Relations Society. 2006. Website guidelines: setting the standard for best practice in investor communications. Available WWW: http://www.ir-soc.org.uk/index.asp?pageid=87 (Accessed 18 May 2007).

Makinson Cowell. 2000. Investor relations websites expectation and reality. Available WWW: http://www.makinson-cowell.co.uk/mc/publications/ (Accessed 3 June 2006).

Marston, C. 1996. The organisation of the Investor Relations Function by Large UK Quoted Companies. Omega, 24(4):477-488.

\section{Appendix A}

\section{South Africa}

\begin{tabular}{|l|l|}
\hline Company name & web site \\
\hline ANGLO AMERICAN PLC & www.angloamerican.co.uk \\
\hline BHP BILLITON PLC & http://www.bhpbilliton.com \\
\hline SASOL LIMITED & www.sasol.com \\
\hline SABMILLER PLC & www.sabmiller.com \\
\hline MTN GROUP LIMITED & http://www.mtn.co.za/ \\
\hline STANDARD BANK GROUP LTD & http://www.standardbank.co.za/ \\
\hline FIRSTRAND LIMITED & www.firstrand.co.za \\
\hline ANGLO AMERICAN PLATINUM CORP LTD & www.angloplatinum.com \\
\hline ANGLOGOLD ASHANTI LIMITED & www.anglogold.com \\
\hline TELKOM SA LIMITED & www.telkom.co.za \\
\hline OLD MUTUAL PLC & www.oldmutual.com \\
\hline ABSA GROUP LIMITED & www.absa.co.za \\
\hline IMPALA PLATINUM HOLDINGS LIMITED & www.implats.co.za \\
\hline REMGRO LIMITED & www.remgro.co.za \\
\hline GOLD FIELDS LIMITED & www.goldfields.co.za \\
\hline SANLAM LIMITED & www.sanlam.co.za \\
\hline NEDCOR LIMITED & www.nedcor.co.za \\
\hline NASPERS LIMITED & www.naspers.com \\
\hline LIBERTY INTERNATIONAL PLC & www.liberty-international.com \\
\hline RMB HOLDINGS LIMITED & www.rmb.co.za \\
\hline KUMBA RESOURCES LIMITED (Re listed Exxaro) & http://www.exxaro.com/content/main/home.asp \\
\hline IMPERIAL HOLDINGS LIMITED & www.imperial.co.za \\
\hline
\end{tabular}




\begin{tabular}{|l|l|}
\hline MITTAL STEEL SOUTH AFRICA LIMITED & www.iscor.co.za \\
\hline LONMIN PLC & www.lonmin.com \\
\hline BARLOWORLD LIMITED & www.barloworld.com \\
\hline HARMONY GOLD MINING COMPANY LIMITED & www.harmony.co.za \\
\hline TIGER BRANDS LIMITED & www.tigerbrands.co.za \\
\hline STEINHOFF INTERNATIONAL HOLDINGS LTD & www.steinhoffinternational.com \\
\hline LIBERTY GROUP LIMITED & www.liberty.co.za \\
\hline INVESTEC PLC & www.investec.co.za \\
\hline EDGARS CONSOLIDATED STORES LIMITED & www.edcon.co.za \\
\hline SAPPI LIMITED & www.sappi.com \\
\hline PRETORIA PORTLAND CEMENT COMPANY LTD & www.ppc.co.za \\
\hline PICK N PAY STORES LIMITED & www.picknpay.co.za \\
\hline WOOLWORTHS HOLDINGS LIMITED & www.woolworthsholdings.co.za \\
\hline JD GROUP LIMITED & www.jdg.co.za \\
\hline ASPEN PHARMACARE HOLDINGS LIMITED & www.aspenpharma.com \\
\hline FOSCHINI LIMITED & www.foschinigroup.com \\
\hline DISCOVERY HOLDINGS LIMITED & www.discovery.co.za \\
\hline NETWORK HEALTHCARE HOLDINGS LIMITED & www.netcare.co.za \\
\hline
\end{tabular}

\section{Egypt}

\begin{tabular}{|l|l|}
\hline Company name & website \\
\hline ORASCOM TELECOM & www.orascomtelecom.com \\
\hline ORASCOM CONSTRUCTION INDUSTRIES & www.orascomci.com \\
\hline TELECOM EGYPT & www.telecomegypt.com.eg \\
\hline VODAFONE EGYPT & www.vodafone.com.eg \\
\hline MOBINIL-EGYPTIAN MOBILE SERVICE & www.mobinil.com \\
\hline EFG-HERMES & www.efg-hermes.com \\
\hline EGYPTIAN IRON AND STEEL COMPANY & www.iron-steel.com.eg \\
\hline COMMERCIAL INTERNATIONAL BANK & www.cibeg.com \\
\hline ORIENTAL WEAVERS & www.orientalweavers.com \\
\hline ORASCOM PROJECTS AND TOURISTIC & www.orascomhd.com \\
\hline EGYPTIAN MEDIA PRODUCTION CITY & www.empc.com.eg \\
\hline AMOUN & www.amoun.com \\
\hline MISR INTERNATIONAL BANK & www.mibank.com.eg \\
\hline EL WATANY BANK OF EGYPT - LE & www.alwatany.net \\
\hline
\end{tabular}

\section{Kenya}

\begin{tabular}{|l|l|}
\hline Company name & Website \\
\hline EAST AFRICAN BREWERIES LTD & www.eabl.com \\
\hline BAMBURI CEMENT LTD & www.bamburicement.com \\
\hline KENYA AIRWAYS LTD & www.kenya-airways.com \\
\hline STANDARD CHARTERED BANK (KENYA) LTD & www.standardchartered.com/ke \\
\hline BRITISH AMERICAN TOBACCO KENYA LTD & www.bat.com \\
\hline BOC KENYA LTD & www.boc.com/contacts/africa/kenya \\
\hline EAST AFRICAN CABLES LTD & www.eacables.com \\
\hline
\end{tabular}


PAN AFRICAN INSURANCE LTD www.pan-africa.com

EXPRESS (KENYA) LTD www.dhl.co.ke

\section{Morocco}

\begin{tabular}{|l|l|}
\hline Company name & website \\
\hline ITISSALAT AL MAGHRIB & www.iam.ma \\
\hline OMNIUM NORD AFRICAIN & www.cinfin.com OR www.ona.ma \\
\hline SOCIETY HOLCIM (MAROC) & www.holcim.ma \\
\hline SOCIETY DE THERAPEUTIQUE MOROCAINE & www.sothema.com \\
\hline AGMA-LAHLOU TAZI S.A & www.agmalahloutazi.ma \\
\hline
\end{tabular}

\section{Nigeria}

\begin{tabular}{|l|l|}
\hline Company name & Website \\
\hline NIGERIAN BREWERIES & www.nbplc.com \\
\hline NESTLE NIGERIA LTD & www.nestle.com \\
\hline GUANRANTY TRUST BANK & www.gtbplc.com \\
\hline UNILEVER NIGERIA & www.unilevernigeria.com \\
\hline OANDO PLC & www.oandoplc.com \\
\hline FIRST CITY MONUMENT BANK & www.fcmb-ltd.com/Fcmb \\
\hline PZ INDUSTRIES & www.pzcussons.com/markets/nigeria.asp \\
\hline UAC NIGERIA & www.uacnplc.com \\
\hline AFRICAN PETROLEUM & www.applcng.com \\
\hline
\end{tabular}

\section{Tunisia}

\begin{tabular}{|l|l|}
\hline Company name & Website \\
\hline ELECTROSTAR & www.electrostar.com.tn \\
\hline
\end{tabular}

\section{Appendix B}

\begin{tabular}{|l|}
\hline \\
\hline Company information \\
\hline Investor relations \\
\hline Web site \\
\hline \\
\hline Financial - Annual Reports \\
\hline Investor relations \\
\hline Web site \\
\hline \\
\hline Financial - Reports Archive \\
\hline Annual reports - Archive \\
\hline Archive - Years \\
\hline
\end{tabular}




\begin{tabular}{|l|}
\hline Relevant News \\
\hline Investor relations \\
\hline Dedicated section \\
\hline Web site \\
\hline Shareholder Information \\
\hline Investor relations \\
\hline Dedicated section \\
\hline Web site \\
\hline \\
\hline Bondholder Information \\
\hline Investor relations \\
\hline Web site \\
\hline \\
\hline Corporate Governance \\
\hline Investor relations \\
\hline Dedicated section \\
\hline Web site \\
\hline \\
\hline Corporate Responsibility \\
\hline Investor relations \\
\hline Dedicated section \\
\hline Web site \\
\hline
\end{tabular}

\section{Disclaimer}

Articles published in SAJIM are the opinions of the authors and do not necessarily reflect the opinion of the Editor, Board, Publisher, Webmaster or the Rand Afrikaans University. The user hereby waives any claim he/she/they may have or acquire against the publisher, its suppliers, licensees and sub licensees and indemnifies all said persons from any claims, lawsuits, proceedings, costs, special, incidental, consequential or indirect damages, including damages for loss of profits, loss of business or downtime arising out of or relating to the user's use of the Website. 
ISSN 1560-683X

Published by InterWord Communications for Department of Information and Knowledge Management, University of Johannesburg 